\title{
Utilization Of Solar Energy For An Ecological Tourism In The Region Of Durrës In Albania
}

\author{
Luiza LLURI \\ "Aleksandër Moisiu" University, Professional Studies Faculty \\ Department of Mechanic and Transport, Durrës, Albania \\ Mob: 355674093313 \\ E-mail: luizalluri@yahoo.com
}

DOI:10.5901/mjss.2014.v5n22p303

\begin{abstract}
This study involves the use of vacuum tubes collector with solar power for heating water for sanitary needs of hotels in the region of Durrës in Albania. Renewable energy resources exist over wide geographical areas, in contrast to other energy sources, which are concentrated in a limited number of countries. Solar energy is a renewable source of energy in our country because Albania belongs to a sub-tropical zone, so it has relatively high levels of solar radiation during the year. The lowlands in the western part of the country have the highest values or irradiation and can produce $139 \mathrm{kwh} / \mathrm{m} 2$ electricity monthly. Durrës region is characterized by a Mediterranean climate where the average air annual temperature is $16^{\circ} \mathrm{C}$ and enters in the area with a high solar radiation with an average $2026 \mathrm{~h} / \mathrm{y}$. Solar energy is clean, reliable and renewable source of electricity and it does not pollute the air by releasing harmful gases like carbon dioxide, nitrogen oxide and sulphur oxide. For this study are obtained tourism hotels in the coastal area of Durrës with a high level of solar intensity, by calculating the cost for heating water using an electric boiler (traditional method) and a solar panel. In the study is selected the collector with vacuum tubes for heating water, which constitutes a new technology with an efficiency $40 \%$ higher than other types. Results show a significant reduction of annual expenses up 3 times, compared with the use of electricity. The results obtained will serve to sensitize residents of the area of Durrës, for the necessity of using solar energy for hot water in residential buildings, where there is sun and the possibility of placing the solar panel. Use of solar panels can also be done in many apartments, which have balcony oriented from the south.
\end{abstract}

Keywords: Renewable energy, solar panel, solar radiation, efficiency.

\section{Introduction}

Albania has favorable conditions for development of solar energy. Albania's solar radiation is calculated at more than $1,500 \mathrm{kWh} / \mathrm{m} 2 / \mathrm{yr}$. The average daily solar radiation is about $4.1 \mathrm{kWh} / \mathrm{m} 2$, reaching more than $4.6 \mathrm{kWh} / \mathrm{m} 2$ in the southwestern part of the country. The country has an average about 2, 400 hours of sunshine per year, 2, 500 hours in the western part and a record of about 2, 850 hours in certain locations. Albania is considered as a country with a better mode of solar energy with high potential of solar radiation. As a country with over 245 day solar radiation intensity, Albania guarantees efficient use of renewable solar energy by significantly reducing the cost of electricity consumption in homes, hotels, service facilities etc. The using solar panels for hot water has years that is started, mainly in villas and tourist hotels in coastal and low areas.

Durrës district is one of 36 districts of Albania with 242.801 inhabitants, an area of $433 \mathrm{~km}^{2}$ and an average height of 2-6 $\mathrm{m}$ above sea level. The city occupies the western part with coordinates $41^{\circ} 18^{\prime} 40^{\prime}$ north latitude to $19^{\circ} 26^{\prime}$ and $21^{\prime}$ east longitude with 1, 626 ha. The table 1 shows the daily average solar radiation in $(\mathrm{kJ} / \mathrm{m} 2)$ and the table 2 shows sunshine hours according to measuring stations in Durres area.

Studies and applications of recent years 1 show that using renewable energy sources of solar, wind and hydro and geothermal, the reliance on fossil fuels can be minimized, leading directly reducing $\mathrm{CO} 2$ emissions. So on average for every $\mathrm{kWh}$ of energy produced from a coal power plant, is produced $1 \mathrm{~kg} \mathrm{CO}$. Combustion of natural gas for electricity production or water heating produces about $450 \mathrm{G} \mathrm{CO} 2$ for every kwh energy produced. By installing solar panels for water

1 http://www.meidasolar.com/service.asp?keyno=113 
heating can provide $50-70 \%$ of energy needs for hot water and it can reduce $\mathrm{CO} 2$ emissions more than $20 \%$. The use of solar panels provides electricity saving, environmental protection and results with economic benefit in the housing sector and services. For this purpose, it is taken in study the coastal area of Durrës, as the tourist area filled with hotels and private experiences are more numerous than in other areas of Albania.

Below are analyzed the solar panels used today, in terms of effectiveness, to choose the most effective type. The effectiveness of the use of solar panels in an average hotel resort is relatively treated with electricity for water heating. This study takes into account only tourist hotels in Durrës.

\section{Methods and Materials}

The study includes 50 hotels 1 with a capacity of about 1600 rooms equipped with shower baths, and a total 60 coffee bars and 60 restaurants. In fact hotels range from the largest with 70 rooms equipped with bathrooms and other fixtures as 2 coffee bars, a restaurant, a night club and a sauna (Hotel "Adriatic"), to the little ones with 12 rooms (Hotel "Ani ") with a coffee bar and a restaurant. The existing hotels are with 3 to 6 floors, with 1 or 2 coffee bar and 1 or 2 restaurants, but there is too with 7 floors and a ground floor area up to $1000 \mathrm{~m} 2$ (Hotel "Dolce Vita"). The average number of rooms results to be 32 for a hotel and 1.2 coffee bar and restaurants. It is taken to an average hotel, with all double rooms equipped with showers with hot water, while at the ground floor there is a coffee bar, a restaurant and the reception.

In this study is used the traditional system, the establishment of an electrical boiler in each bathroom. For all the hotel are planned: 32 boilers and 4 boiler for coffee bar, restaurant etc. So should be 36 electrical bolier with capacity of 80 liters and $2 \mathrm{kwh}$ electricity power each. At the under hand is taken into consideration the use of the solar panel with vacuum tubes, as the model with higher effectiveness. The size of the collector is determined by absorber surface formed by vacuum tubes.The absorber surface for vacuum tubes is given by size of the tubes as follows [8]: For tubes with dimensions $58 \mathrm{~mm} \times 1800 \mathrm{~mm}$ have $\mathrm{S}=0.08 \mathrm{~m} 2$ per tube. Collectors are standardized with 12, 18, 24, 30, 36, 48 and 60 tubes, which correspond to the respective boilers with hot water capacity $100 \mathrm{~L}, 150 \mathrm{~L}, 200 \mathrm{~L}, 250 \mathrm{~L}, 300 \mathrm{~L}, 400 \mathrm{~L}$ and $500 \mathrm{~L}$. Capacity over $300 \mathrm{~L}$ used for hotels.

\section{Procedure}

\section{Energy for water heating in Durrës hotels}

The effectiveness of providing hot water is calculated by analyzing two methods: 1 .heating water using electricity with electric boilers and 2.heating water using solar panels with vacuum tubes. Average annual costs for heating water are calculated for each variant considering that all the hotel rooms are in operation. Also are estimated reductions of carbon dioxide emissions as result of solar panels for water heating and annual operating costs for electric heating and solar panels.

Heating water with an electric boiler

The need for a person must be 58 liters of warm water with $420 \mathrm{C}-450 \mathrm{C}$ in the day. By assuming that all the hotel rooms are doubles, and consumption of hot water at the bar and restaurant is the same with room boilers, in total with losses of water for all the hotel have to be about 3600 liters per day. Assuming that the people in the hotel shower for the day is done, we can assume that the energy values for a boiler with all anticipated losses, amounts to $120 \mathrm{kwh} / \mathrm{month}$. Consumed electricity for the entire hotel is $4320 \mathrm{kwh} /$ month and for all hotels in the area of Durrës, $21600 \mathrm{kwh} / \mathrm{month}$.

Heating water using solar panels

Having received an average difference of water temperatures at the entrance and exit about $300 \mathrm{C}$, the number of vacuum tubes, required for water heating is determined:

$$
\mathrm{N}=\mathrm{k} \text { AED }(\mathrm{BF}) / \mathrm{S}
$$

where: $\mathrm{k}$ is the coefficient, that gives the amount of solar energy, which have to heat one liter of water, which depends on the level of solar technology and hydraulic losses in the Network. Thus the total number of pipes for heating 3,600 liters of water, calculated in months, given in figure 2 .

\footnotetext{
${ }^{1}$ Albania online travel Agency; www.edialtour.com
} 
The average number of pipes to realize water heating, results 472 tubes. With reserve (for January and December is used and an electric heater, if the hotel rooms are all in place), are choosen collectors with 60 tubes with boiler 500 liters.

In this case the thermo-hydraulic scheme requires, that in the roof of average hotel it is placed 8 sets of collector with 480 tubes with a total area of $38.4 \mathrm{~m} 2$.. The total capacity of hot water boilers is 4000 liters. The time of depreciation of equipment and solar panels is greater than 15 years.

The energy amount produced by solar panels for water heating in $\mathrm{kWh}$ is calculated: $\mathrm{W}=\mathrm{K}$ EDS

where: $\mathrm{K}$ - is the average coefficient that determines the amount of energy equivalent to heating the water with one $\mathrm{m} 2$ area solar panel, which depends on the level of solar technology and hydraulic losses in network. For hotel taken as example, the amount of daily and monthly energy generated from solar panels by months of the year, is given in figure 3 . The average amount of daily energy saving for this hotel would be $120 \mathrm{kWh} /$ day or $3600 \mathrm{kWh} / \mathrm{month}$. For all tourist hotels in the Durrës area it will assure an electrical energy saving in the about $6000 \mathrm{kWh} /$ day, or $30,000 \mathrm{kWh} / \mathrm{month}$.

\section{Reducing carbon dioxide emissions}

For hotel takes into consideration, the reduction of $\mathrm{CO} 2$ gas is calculated by the given method1, by months of the year (figure 4).The graph shows that the maximum amount of reducing gas $\mathrm{CO} 2$ occurs during the summer months, when it is the tourism season, providing a significant reduction of environmental pollution from gas CO2 to an average $48 \mathrm{~kg} / \mathrm{month}$ and during the summer months to $55 \mathrm{~kg}$. The average value of the amount of $\mathrm{CO} 2$ gas will be $576 \mathrm{~kg} / \mathrm{year}$, only for this hotel.

\section{Average annual cost analysis}

Average annual expenditures are made by calculating for 10 years, for each option the costs for: Initial investment of installing,

Expenses incurred during the annual usage,

Maintenance of installation

For heating systems with an electric boiler, investments for a bath go to 200 Euro, and the total for all hotel 7200 Euro (figure 5). The period of amortization for the hydraulic system and boiler goes up to 8 years. In expenses incurred during the annual usage, it is included the cost of electricity for 10 years. Electricity costs will be 432 Euro/month, acknowledging the current price of energy about 0.1 Euro/Wh. In maintaining of installation it is included changes of electric boilers and repairs of the tubes.

For systems with solar panels, all investments with fixing2 will be: $8 \times 5100=40,800$ Euro, spending the use is free (solar energy). In maintaining of the installation it is included the change of broken pipe, and any faulty electrical equipment, which are too small.

\section{Results}

Results (figure 5) show that initial investiment for electric heating is small, while for solar heating is 3 times larger. For electric heating annual operating costs are higher, while for solar panels are very small.

In conclusion we see that the annual average cost for 10 years to water heating with electric side is 3 times larger than it received through the use of solar panels. This coincides with the data of special literature, that the energy consumed for heating of 100 liters of water through solar panels with vacuum tubes, is 3.5 times smaller compared to electric heating. While it is noted that initial investiment of solar panels can be deleted after 3 years. For all tourist hotels in Durrës area, we have a reduction of gas $\mathrm{CO} 2$, to $240 \mathrm{~kg} / \mathrm{month}$, or $2880 \mathrm{~kg} \mathrm{CO} / \mathrm{year}$, providing a major contribution in reducing global warming and in climate regulation.

\footnotetext{
${ }^{1}$ http://www.meidasolar.com/service.asp?keyno=113

2 Multi Force shpk; multiforce_tirana@yahoo.com
} 


\section{Acknowledgments}

The first parameter that must be defined to perform this study, is the demand for energy providing hot water for a typical day and it is calculated by formula 1 :

E daily demand $=\mathrm{N}$ people $\times$ Vwarm water $\times$ Cthermal capacity $\times($ T0 output $-\mathrm{TO}$ input $)$ (1)

Monthly demand for energy for providing hot water is calculated from the formula 2 :

E monthly demand $=\mathrm{N}$ days $\times$ Edaily demand (2)

Annual demand for energy for providing hot water is calculated from the formula 3 :

E annual demand $=\sum$ E monthly demand (3)

Power supply for the provision of hot water per month is calculated according to the formula 4 :

$\mathrm{E}$ monthly supply $=\mathrm{N}$ days $\times \mathrm{I}$ solar radiation $\times \mathrm{A}$ solar panel $\times \mathrm{E}$ effic. of system (4)

where:

$\mathrm{N}$ days $=$ The number of days under each respective month

I solar radiation = Average daily solar radiation $[\mathrm{kJ} / \mathrm{m} 2$, day $]$

A solar panel $=$ Surface solar water heating

E effic. of system $=$ System efficiency solar water heating

Power supply for the provision of hot water per year is calculated according to the formula 5 :

$$
\text { E annual supply }=\sum \text { E monthly supply (5) }
$$

According to a study by ERE1, water heating in albanian households is with electricity. The average value of consumed energy for a family is $58 \mathrm{kwh} /$ month or $19 \%$ of all electricity consumed.

The burning of fossil fuels like coal to produce electricity and gas or diesel for water heating release large amounts of $\mathrm{CO} 2$ in the atmosphere, but the use of solar panels for water heating also contributes to reducing environmental pollution.

On rainy days or overcast dense, the energy production will be reduced greatly. In determining the size of solar collectors needed to provide hot water should be given this information [7]:

A - daily needs for hot water

$B$ - water temperature at the outlet

C - area of the installation of solar panel

D - maximum monthly solar level

$\mathrm{E}$ - average efficiency of solar collector in the maximum radiation

$\mathrm{F}$ - water temperature at the entrance

$\mathrm{G}$ - specific heat in $\mathrm{kal} / \mathrm{kg} \mathrm{oC}$

Level of solar radiation is given available from the site of the sun. Maximum and minimum levels should be taken into account throughout the year, as well as the annual average value. Specifically in the area of Durres, the level of solar radiation measured [5] in $\mathrm{kwh} / \mathrm{m} 2$, is presented in figure 1.

Temperature of hot water should usually be around $420 \mathrm{C}$ to $45^{\circ} \mathrm{C}$. Cold water temperature is usually in the soft regions varies from $10 \mathrm{oC}$ in winter to $20 \mathrm{oC}$ in summer. Besides the above used factors it should also be taken into account the optimum installation angle, which must be: $20-70^{\circ}$ Vertical, -5 to $+5^{\circ}$ horizontal, the installation required site of the collector in the roof and part of days without sun, which makes that for the month to be taken 28 days and for year 336 days. Average

\footnotetext{
${ }^{1}$ Energy Regulatory Office; ; www.ere.gov.al
} 
loss coefficient taken $0.8 \mathrm{~W} / \mathrm{m} 20 \mathrm{C}$, while the average efficiency of the absorber solar energy is taken 0.8-0.92. Recognizing the latitude for the area of Durrës, referring collector tilt versus horizontal [6] it is fixed degrees of tilt of collectors.

\section{Discussion}

Solar panels with vacuum tubes, have an absorption efficiency of solar energy $40 \%$ greater than panels with mirrors and it does not depend on incline of the radius sun.

The using of solar panels systems with vacuum tubes to provide hot water in tourist hotels in Durrës area, lead to a saving of electricity and the total expenditure up to 3 times.

Using the vacuum collector tubes can also be used in apartments which have a balcony from the face of the sun and is very efficient for providing of sanitary hot water, saving energy and costs up to 3 times.

Central and local government in our country, should set rules to force the introduction of new technologies of using solar energy in the design phase of villas, hotels and buildings in coastal and low areas.

The use of solar energy by businesses or consumers reduces household electricity bills that is spent on heating water to the extent of $30 \%$.

By replacing an electric water heater with a solar water heater, can reduced greenhouse gas emissions up to 3 tonnes a year, contributing to environmental protection.

These systems are usually located on rooftops and provide higher security by eliminating the risk of accidents due to electric water heating equipment.

The high potential of solar radiation and favorable geographical position is a possibility that nature provides for the use of solar energy to produce hot water for sanitary needs and electrical energy.

Measures for the use of solar energy, are investments in the right direction, and contribute directly to long-term sustainable development and the reduction of energy consumption costs.

This study will serve as an incentive for increased use of solar thermal panels for hot water because their use is currently in the very low range.

\section{References}

Althous A.D, Turnquist C.H, .Bracciano A.F. "Modern refrigeration and air conditioning ". llinois 1988.

Demneri I., Shtjefni A. "Termoteknika” Tiranë 2007.

Europieiskie solnecnie instalacii. Projekti Demo Solar. Bruksel 2002.

Mario A CUCUMO, Valerio MARINELLI, Giuseppe OLIVETTI. "Ingeneria solare. Bologna "1994.

Minguli F., Shtjefni. A."Aspekte të shfrytëzimit të energjisë diellore në zonën e Durrësit". Seminar i Q E E. Tiranë 2001.

Miço Mirel, Çiçolli Elona ." Dimension of solar panels surface based to the net present value for the albanian

conditions". Journal of Environmental Science and Engineering A 2 (2013) 464-467 ISSN 1934-8932.

Online International Interdisciplinary Research Journal, \{Bi-Monthly\}, ISSN 2249-9598, Vol-IV, Jan 2014 Special Issue

Solar energy in Albania. National agjency of Natural resourses. http://www.akbn.gov.al/

Tecnologie solari. "Raccolta tecnica da F E A" Roma 2005.

Voshtina L. "Ngrohja , ventilimi dhe klimatizimi i ndërtesave". Tiranë 2002.

\section{Appendices}

Table 1 Daily average solar radiation in $(\mathrm{kJ} / \mathrm{m} 2) 1$

\footnotetext{
$1 \mathrm{http}: / /$ aea-al.org/wp-content/.../04/RENEWABLE-ENERGY-ALBANIA
} 
Month Jan Feb March April May June July August Sept Oct Nov Dec

Durrës $1320513523 \quad 14347 \quad 17604 \quad 1863720228 \quad 22277 \quad 2319920305 \quad 17750 \quad 5347 \quad 14677$

Table 2 Sunshine hours according to measuring stations

Hours with sun (h/year)

$\begin{array}{lccccc}\text { Year } & 1951-1960 & 1961-1970 & 1971-1980 & 1981-1990 & \text { Average, 1951-2005 } \\ \text { Durrës } & 2666 & 2684 & 2717 & 2310 & 2595\end{array}$

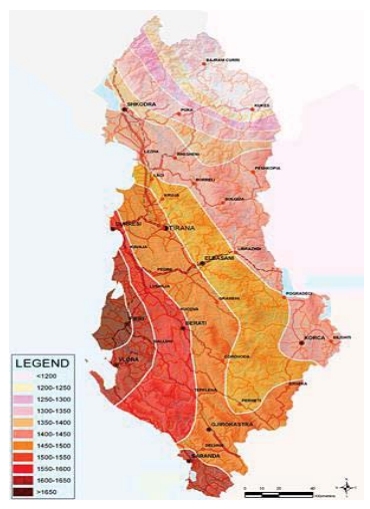

Legend: The average annual radiation $\mathrm{kWh} / \mathrm{m} 2$ sunshine

Source: Institute of Hydro Meteorology

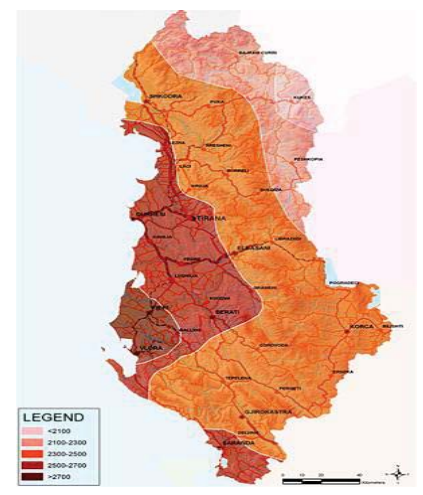

Legend: Territorial distribution of hours of Source: Institute of Hydro Meteorology

Figure 1. The level of solar radiation in the Durres area

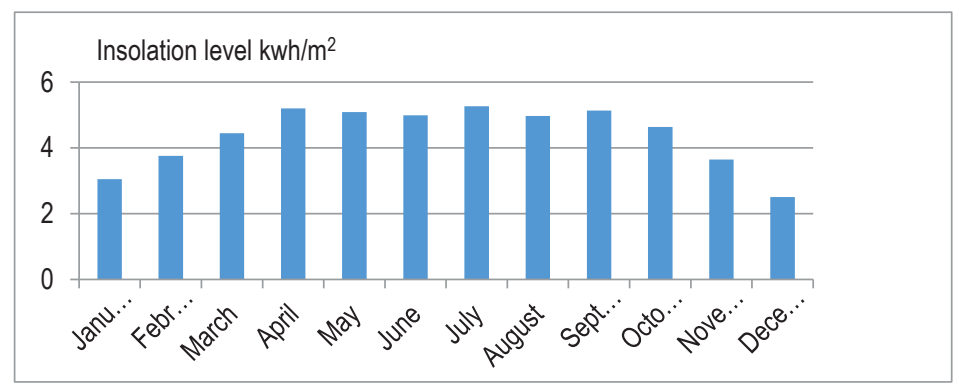

Figure 2. The number of vacuum tubes by months of the year

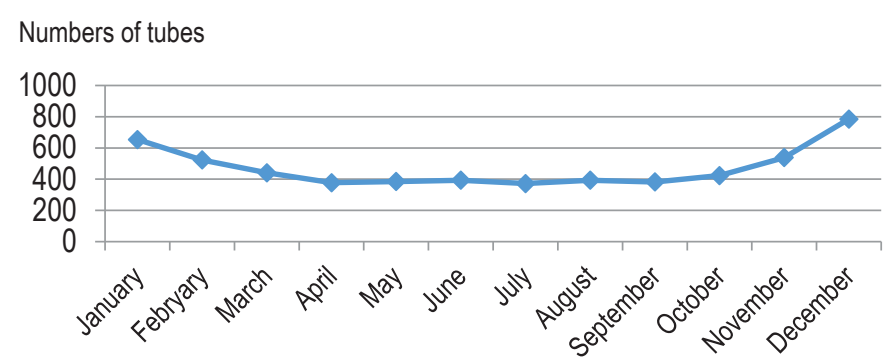


Figure 3. The amount of energy produced by solar panels

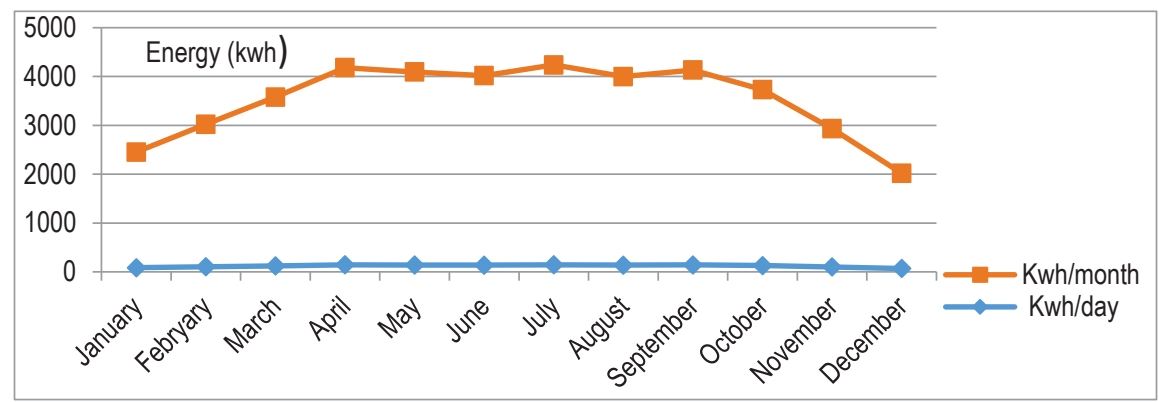

Figure 4. Reduction of $\mathrm{CO} 2$ gas during the year

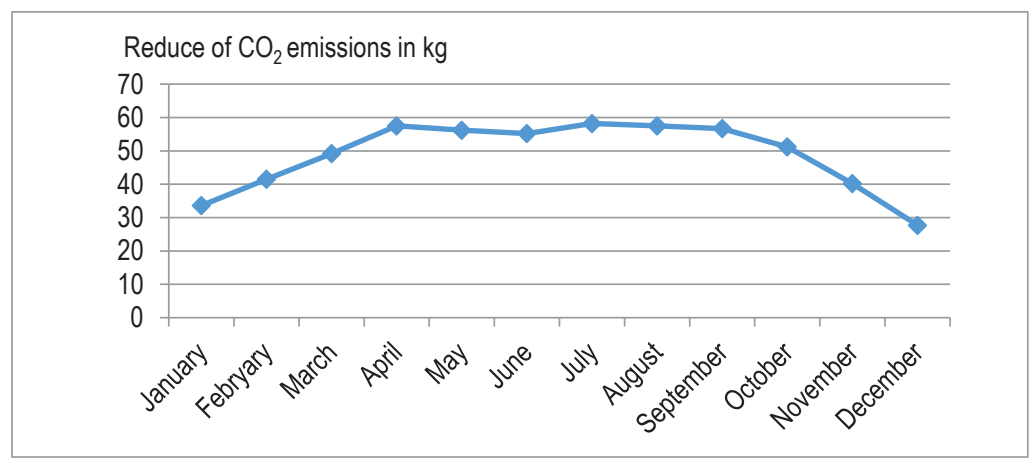

Figure 5. Expenditures for hot water with electric boiler and solar panels

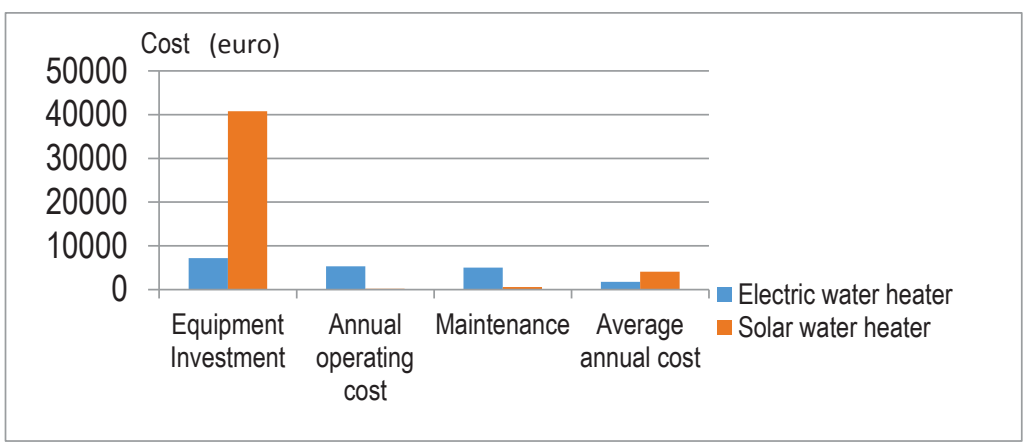

